\title{
The Basic Characteristics of Marx's Political Philosophy
}

\author{
Tiefeng Lai \\ School of Marxism, Heilongjiang Bayi Agricultural University, Daqing, China \\ Email: 46430833@qq.com
}

How to cite this paper: Lai, T. F. (2020). The Basic Characteristics of Marx's Political Philosophy. Open Journal of Social Sciences, 8, 313-319.

https://doi.org/10.4236/jss.2020.88026

Received: July 28, 2020

Accepted: August 22, 2020

Published: August 25, 2020

Copyright $\odot 2020$ by author(s) and Scientific Research Publishing Inc. This work is licensed under the Creative Commons Attribution International License (CC BY 4.0).

http://creativecommons.org/licenses/by/4.0/

\begin{abstract}
Marx's thought is broad and profound, but it is inseparable from the word "human". As an important part of Marx's thought, his political thought is no exception. It can be said that in the course of Marx's thinking on politics, the brilliance of human nature has always been shining. His political theory vision has never left human beings themselves. Marx's political thought is a peopleoriented political philosophy. The purpose of this paper is to grasp the basic connotation of Marx's political philosophy through research, and the main research methods are literature research and analysis.
\end{abstract}

\section{Keywords}

Human Nature, Political Philosophy, Fairness, Justice, Man's All-Round Development

\section{Introduction}

Marx devoted his whole life to the thought and practice of emancipating human beings. His concern for human beings is the starting point and end point of all his thoughts, so that some later scholars regard Marxism as a kind of human science.

Marxist Political Science attributes the root of human social conflicts to social relations of production. Its great significance lies in putting the political science research on a realistic and materialistic basis. It also has a profound impact on the development of modern western political science.

The study of Marx's political philosophy is conducive to understanding Marx's criticism of capitalist production relations and the conception of an ideal Communist society. The goal of this study is to summarize the basic characteristics of Marx's political philosophy. 


\section{Main Content}

Marx's political philosophy is his view on the nature of political relations and the general law of its development, including political value, political system and political ideal. Here, we can understand the main content of Marx's political philosophy by analyzing its theoretical basis, basic principles, goals and paths.

On the significance of studying Marx's political philosophy, Zou Weizhong believes that in order to carry out scientific political reform and promote political and social development, it is necessary to have a profound reflection on the real political life, and to examine, interpret and guide the solution of some fundamental major practical political problems from the perspective of Marxist philosophy as a whole (Zou, 2011).

As for the research theme of political philosophy, Zhang Dun believes in "Marx's political theory and its path" that Marx has brought great changes to modern political theory, which is to transfer the central field of politics from the traditional state and law to the economic field. By revealing the nature of power oppression of capitalist economy, a new field of political theory is opened up, and the core content is the theory of class and class struggle (Zhang, 2006).

Zou Shipeng put forward in "the revival of contemporary political philosophy and the tradition of Marxist political philosophy", that political liberation must lead to human liberation. Political liberation is only an intermediary, and human liberation is the purpose. Marx's political philosophy is subject to his overall philosophical anthropology. Marx's theory of human liberation and its political value is the main level of Marx's political philosophy (Zou, 2006).

In the history of political philosophy, Leo Strauss and Joseph Kropossi hold that Marxist historical materialism contains the dimension of political philosophy, and Marxist political philosophy is the embodiment and deepening of historical materialism (Strauss \& Cropsey, 1998).

This paper will follow the ideas of these scholars, expounding and analyzing the basic characteristics of Marx's political philosophy.

\subsection{Marx's Understanding of Human Nature Is the Basis of His Political Philosophy}

As in China, the debate on the good and evil of human nature has a long history in the West. The ancient Greek and Roman classical civilization and the ancient Hebrew religious civilization have different opinions on the theory of human nature, which have different influences on political and cultural concepts (Zuo \& Xiao, 2015).

Christianity believes in the theory of human nature of original sin that human beings are born with sin. People have the intention of doing evil and committing crimes since they were born. It is precisely because people have a natural tendency to do evil, so the commandments that restrict people's behavior are indispensable. Machiavelli, a modern political scientist, based on human nature and its inherent defects, established the human nature of politics on the basis of ex- 
perience. He found a logical starting point of the reality of evil personality for western political science. After him, Locke, Hobbes and others put forward social contract theory, power balance theory and legal thought from the theory of evil nature, thus building the theoretical basis of modern western political system. The human nature basis of Hobbes' political thought is individualism. He thinks that human beings are selfish in nature. It is the nature of natural people to be full of malice, brutality and aggression. Man is driven into the "war of all men against all men" (Yu, 2017) by nature. The only strategy to solve the situation of hostility between people is to establish a government with absolute authority. Therefore, Locke, Hobbes and others advocate to maintain social order through power balance, legal sanctions and public opinion supervision. After Hobbes, many political theories are based on different views about "natural person".

There are different views on human nature and its influence on political system. Plato, an ancient Greek philosopher, once regarded human morality as the basis of politics. He believed that to establish an ideal country, we should not only establish the hierarchical order, but also ensure the good character of citizens. It is the noble character in human nature that overcomes the despicable character. Rousseau insists that the selfish man described by Hobbes is not a natural person, but a product of modern society. In his opinion, natural people have no sense of time, self-consciousness and desire to attack. Therefore, natural people are innocent and innocent, regardless of good and evil. Thomas Moore and Tommaso Campanella, the successors of the theory of good nature, made a more in-depth discussion on the nature of human kindness and constructed utopian ideal, which had a great impact on Marx's Communist theory.

Although Marx did not specifically discuss the good and evil of human nature, we can see that he held an optimistic attitude towards human nature, which influenced him to attribute the root of social conflict to objective factors other than human nature. He believes that the conflict and confrontation between people in social life do not originate from the natural nature of human beings, but the confrontation growing out of individual social living conditions, which is the mode of social production. The mode of social production is not only a way of people's common activities, but also a form of confrontation leading to conflicts and confrontation between people. In private ownership society, according to the form of private ownership of means of production, society is divided into several classes, and the struggle between classes constitutes the main form of social conflict and confrontation. Since private ownership is the root of social conflicts, the way to solve the conflicts is to eliminate private ownership. Once the private ownership is eliminated, the class will die out and the subject of social conflict will disappear. At the same time, he believes that social conflict and confrontation are only temporary phenomena, while social harmony and consistency are eternal and universal. The way to achieve social harmony and consistency is to eliminate private ownership and establish a communist society. In 
the Communist society, all conflicts and confrontations will eventually be resolved. Different from Plato's Utopia, the Communist society conceived by Marx is based on practice and revolution, which is scientific and realistic; while Plato is based on theoretical conception and is a kind of Utopia.

\subsection{Fairness and Justice Is the Basic Principle of Marx's Political Philosophy}

In the history of political thought, fairness and justice is an eternal theoretical theme discussed from different angles. People's design and imagination of the future ideal society contain the desire for social fairness and justice. Marx opposed to explaining history and criticizing society from various abstract principles of justice, and advocated that the material activities of individuals or the whole should be taken as the basis and principle for the realization of fairness and justice.

Marx's thought of fairness and justice is based on the profound analysis of the realistic social and economic relations. Different from the theory of human nature in the 17th and 18th centuries, which expounded the issue of fairness and justice from the abstract principles, Marx attached great importance to understanding the issue of fairness and justice from the perspective of social and economic life. Fairness and justice are not abstract human rationality. "The conclusion that neither legal relations nor forms of state could be grasped whether by themselves or on the basis of a so-called general development of the human mind, but on the contrary they have their origin in the material conditions of existence" (Marx \& Engels, 2009).

Law, as a standard of fairness and justice, aims to maintain a specific mode of production and social order. For Marx, the essence of capital is neither material nor money, but a kind of production relationship. Since capitalist labor is wage labor, it is impossible to realize labor equality and fair distribution of products. Under the condition of capitalist private ownership, freedom, equality and justice are abstract, formal and hypocritical. They are not real freedom, equality and justice in reality. Marx sharply criticized the hypocrisy of capitalist economic equality. The bourgeoisie's political liberation marked by the establishment of the so-called universal freedom, equality and human rights has obvious limitations. On the basis of criticizing the abstractness and formality of the justice principle of western capitalism and the irrationality and injustice of capitalist production relations, and in the process of exploring the solutions to the internal contradictions in the realistic capitalist relations of production, Marx believes that the real social justice is only possible in the Communist society.

From criticizing the bourgeoisie's abstract view of justice, to the later political economic criticism, and finally to the Communist social conception, Marx's view of fairness and justice has always been based on the decisive role of economic foundation, and advocated that fairness and justice can only be correctly understood in material production, thus regarding property equality as the premise of human social justice and discarding private property as fairness and jus- 
tice the way to achieve it. Only through the revolution, abolishing the capitalist property private ownership, eliminating exploitation and oppression, can the social system be just and reasonable in the Communist society, the relationship between people is a real equal relationship, the freedom of human comprehensive development can be realized, and the goal of fairness and justice of human society can be realized (Li, 2019).

\subsection{Man's All-Round Development Is the Ultimate Goal of Political Philosophy}

The thought of Marx's political philosophy is concentrated in the works such as critique of political economy, German Ideology, Manifesto of the Communist Party, etc. in these works, Marx's political ideas all show his ultimate concern for the individual and the whole person. From the perspective of political philosophy, it expounds that human liberation is the future form and final destination of political liberation. It seems that the future society is the union of free people, and the state of future people is free and all-round development.

The "freedom" in such concepts as "free man" and "the association of free man" mentioned by Marx is not limited to the freedom discussed from the perspective of political relations. In his opinion, freedom is not a kind of human right, but a kind of human characteristic. If political life is regarded as a boundary, then human can fully realize individual freedom. However, if the scope of observation is extended to the natural world, then for human survival and development, human freedom is limited. Therefore, political freedom is only human beings in class society. The helpless choice under the survival. Political liberation itself is not human liberation. Marx always believed that democracy is not the social mechanism of Communist society (Li, 2018), and the existence of democracy is the sign of the continued existence of the state. Therefore, it is impossible for Marx to regard democracy as the political goal of his liberation, and the free and all-round development of human beings is the ultimate goal of political development, even if the political state dies out God. Those who interpret Marx's theory of human liberation and human freedom from the scope of political life only see the superficial category of political philosophy, which is not helpful for us to correctly understand Marx's communist ideal. In the Manifesto of the Communist Party, Marx demonstrated in detail various incorrect socialist theories, systems and other realistic political factors because he organically linked the theory of human liberation with the proletarian revolution, dictatorship and party theory.

\subsection{Communication Is the Fundamental Way to Realize the Ultimate Goal of Political Philosophy}

Marx's humanistic politics is not for political liberation, but for human liberation. Human freedom is not a humanitarianism of individual freedom, but "Man appropriates his comprehensive essence in a comprehensive manner, that is to say, as a whole man" (Marx \& Engels, 2009). How to realize the return of human 
nature and the free and all-round development of human beings? Marx pointed out a realistic way for us: communication.

In German Ideology, Marx pointed out that "The first premise of all human history is, of course, the existence of living human individuals", "but of individuals, not as they may appear in their own or other people's imagination, but as they really are; i.e. as they operate, produce materially, and hence as they work under definite material limits, presuppositions and conditions independent of their will", "A person's development depends on the development of all others who interact with him directly or indirectly" (Marx \& Engels, 2009). In Marx's view, communication and human development are closely linked. Marx revealed the mutual relationship and value significance between the two, pointed out the relationship between human development and communication: the existence and development of individual human is the primary prerequisite for the development of production and communication, and communication plays a decisive role in human survival and development. Communication activities are the relationship between subjects and between subjects and objects. In different periods of human development, due to the differences between subjects and historical environment, communicative activities show different forms. Marx's three-stage theory of the development of human resources logically and historically expounds the relationship between communication and human development. Marx believed that the evolution of the relationship from the dependence of people to the dependence of people on things, and finally to the free communication between people in the communist ideal reflects the return track of human nature from being enslaved by others, being enslaved by things, to free and all-round development.

Marx advocated to realize the ultimate political goal of human free and all-round development through communication, which also had a great impact on the later construction of political ethics. Habermas, as a representative of new Marxism, hopes to establish communication rationality and take the road of communication practice as the way to realize fairness and justice. In the political ethics platform with communication as the means, all people are the subjects of dialogue and communication, from subjectivity to intersubjectivity, and from practical rationality to communicative rationality, so as to realize an ideal political dialogue structure.

To sum up, Marx's political philosophy based on his optimistic understanding of human nature, and then attributed the root of human social conflicts to social production relations. In his opinion, fairness and justice are the basic principles of human society and political operation, which can be understood correctly in material production. Only by sublating private property can it be possible to further realize the free and all-round development of human beings. The premise of all this is the relationship between subjects and objects.

\section{Conclusion}

Through the above research, we can see that Marx's political philosophy always 
adheres to the people-oriented principle, denies the construction of pure Utopian political philosophy from the aspects of abstract consciousness and ethical concepts, and takes "realistic individual" as the historical premise of human society, so as to advocate relying on advanced political subjects to seek legal, legitimate and superior social system, and finally realize human beings Fairness and justice of quasi society and free and all-round development of human beings (Jin, 2011).

From the perspective of theoretical value, Marx's political philosophy has achieved the unity of scientific and revolutionary nature, ideal and practical nature of political philosophy. The concept of people-oriented governance, the pursuit of fairness and justice, and the political ideal of human liberation embodied the advanced value concept of Marx's political philosophy.

\section{Conflicts of Interest}

The author declares no conflicts of interest regarding the publication of this paper.

\section{References}

Jin, R. H. (2011). Looking at the All-Round Development of Contemporary People from the Perspective of Marx's World History Theory. Journal of Guangxi Institute of Socialism, 22, 9-12.

Li, K. X. (2019). Research on Marx's Justice Thought from the Perspective of Historical Materialism. Beijing: Capital University of Economics and Trade.

Li, L. S. (2018). Research on Marx's Theory of Human Liberation. Lanzhou: Northwest Normal University.

Marx \& Engels (2009). The Compilation Bureau of the Central Committee of the Communist Party of China. Collected Works of Marx and Engels.

Strauss, L., \& Cropsey, J. (1998). History of Political Philosophy (I) (Trans. Li Tianran et al.). Shijiazhuang: Hebei People's Publishing House.

Yu, Q. (2017). On Marxist Theory of Human Nature Thought. Reform and Opening Up, No. 2, 52-53.

Zhang, D. (2006). Marx's Political Theory and Its Path. Chinese Social Sciences, 5, 33-45.

Zou, S. P. (2006). The Revival of Contemporary Political Philosophy and the Tradition of Marxist Political Philosophy. Academic Monthly, 12, 25-33.

Zou, W. Z. (2011). Continuation and Construction: A Review of the Domestic Research on Marxist Political Philosophy in Recent Years. Climbing, 30, 31-35.

Zuo, L. P., \& Xiao, C. P. (2015). On the Human Dimension of Marx's Political Ethics. Journal of Yellow River University of Science and Technology, 17, 57-60. 